\title{
The maintenance of elevated active chlorine levels in the Antarctic lower stratosphere through $\mathrm{HCl}$ null cycles
}

\author{
Rolf Müller $^{1}$, Jens-Uwe Grooß ${ }^{1}$, Abdul Mannan Zafar ${ }^{1, a}$, Sabine Robrecht ${ }^{1}$, and Ralph Lehmann ${ }^{2}$ \\ ${ }^{1}$ Institute of Energy and Climate Research (IEK-7), Forschungszentrum Jülich, Jülich, Germany \\ ${ }^{2}$ Alfred Wegener Institute, Helmholtz Centre for Polar and Marine Research, Potsdam, Germany \\ apresent address: Institute of Environmental Engineering and Research, University of Engineering and Technology, \\ Lahore, Pakistan
}

Correspondence: Rolf Müller (ro.mueller@fz-juelich.de)

Received: 6 September 2017 - Discussion started: 23 October 2017

Revised: 19 December 2017 - Accepted: 22 December 2017 - Published: 1 March 2018

\begin{abstract}
The Antarctic ozone hole arises from ozone destruction driven by elevated levels of ozone destroying ("active") chlorine in Antarctic spring. These elevated levels of active chlorine have to be formed first and then maintained throughout the period of ozone destruction. It is a matter of debate how this maintenance of active chlorine is brought about in Antarctic spring, when the rate of formation of $\mathrm{HCl}$ (considered to be the main chlorine deactivation mechanism in Antarctica) is extremely high. Here we show that in the heart of the ozone hole $(16-18 \mathrm{~km}$ or $85-55 \mathrm{hPa}$, in the core of the vortex), high levels of active chlorine are maintained by effective chemical cycles (referred to as $\mathrm{HCl}$ null cycles hereafter). In these cycles, the formation of $\mathrm{HCl}$ is balanced by immediate reactivation, i.e. by immediate reformation of active chlorine. Under these conditions, polar stratospheric clouds sequester $\mathrm{HNO}_{3}$ and thereby cause $\mathrm{NO}_{2}$ concentrations to be low. These $\mathrm{HCl}$ null cycles allow active chlorine levels to be maintained in the Antarctic lower stratosphere and thus rapid ozone destruction to occur. For the observed almost complete activation of stratospheric chlorine in the lower stratosphere, the heterogeneous reaction $\mathrm{HCl}+\mathrm{HOCl}$ is essential; the production of $\mathrm{HOCl}$ occurs via $\mathrm{HO}_{2}+\mathrm{ClO}$, with the $\mathrm{HO}_{2}$ resulting from $\mathrm{CH}_{2} \mathrm{O}$ photolysis. These results are important for assessing the impact of changes of the future stratospheric composition on the recovery of the ozone hole. Our simulations indicate that, in the lower stratosphere, future increased methane concentrations will not lead to enhanced chlorine deactivation (through the reaction $\mathrm{CH}_{4}+\mathrm{Cl}$ $\longrightarrow \mathrm{HCl}+\mathrm{CH}_{3}$ ) and that extreme ozone destruction to levels below $\approx 0.1 \mathrm{ppm}$ will occur until mid-century.
\end{abstract}

\section{Introduction}

Because of the success of the Montreal Protocol and its amendments and adjustments, the atmospheric halogen loading peaked in the early 1990s and has been declining slowly since then. Even today, the Montreal Protocol has already achieved significant benefits for the ozone layer and the Antarctic ozone hole (by 2013; Chipperfield et al., 2015). Nonetheless, model simulations predict that the Antarctic ozone hole will continue to occur for decades (e.g. WMO, 2014; Oman et al., 2016; Fernandez et al., 2017).

The rapid chemical destruction of ozone in the Antarctic stratosphere in spring is caused by catalytic cycles driven by $\mathrm{ClO}$ and $\mathrm{BrO}$ (McElroy et al., 1986; Molina and Molina, 1987; Solomon, 1999). To run efficiently, these catalytic cycles require large concentrations of "active chlorine, $\mathrm{ClO}_{x}$ " $\left(\mathrm{ClO}_{x}=\mathrm{ClO}+2 \times \mathrm{Cl}_{2} \mathrm{O}_{2}+\mathrm{Cl}\right)$. The activation of chlorine, i.e. the conversion of the main chlorine reservoir species $\left(\mathrm{HCl}\right.$ and $\left.\mathrm{ClONO}_{2}\right)$ to $\mathrm{ClO}_{x}$, occurs through heterogeneous reactions (Solomon, 1999). The initial step of chlorine activation proceeds via the heterogeneous reaction (Solomon et al., 1986)

$\mathrm{ClONO}_{2}+\mathrm{HCl} \rightarrow \mathrm{Cl}_{2}+\mathrm{HNO}_{3}$

this step occurs very rapidly during polar night in about midMay, when temperatures become low enough for heterogeneous chlorine activation. Because of the initial concentration of $\mathrm{HCl}$ (before the onset of heterogeneous reactions) in the polar vortex being greater than that of $\mathrm{ClONO}_{2}(\mathrm{Jaegle}$ et al., 1997; Santee et al., 2008), the amount of $\mathrm{Cl}_{2}$ produced 
initially in Reaction (R1) is limited by the amount of available $\mathrm{ClONO}_{2}$ (Salawitch et al., 1988; Crutzen et al., 1992; Portmann et al., 1996). The further chemical activation to near-zero $\mathrm{HCl}$ values, as observed in Antarctic winter and in cold winters in the Arctic (Jaeglé et al., 1997; Santee et al., 2005, 2008; Manney et al., 2011; Wegner et al., 2012), requires the reproduction of partners (e.g. $\mathrm{ClONO}_{2}$ or $\mathrm{HOCl}$ ) for heterogeneous reactions with $\mathrm{HCl}$.

With the return of sunlight to the polar region a period follows, characterised by further activation and maintenance of high levels of active chlorine (as observed; Santee et al., 2005, 2008), during which most of the ozone depletion occurs. Polar stratospheric clouds are measured in the Antarctic lower stratosphere until early October (Pitts et al., 2009). However, which chemical processes are responsible for further activation and maintenance of active chlorine is a matter of debate (Solomon et al., 2015).

Here, for the heart of the ozone layer (in the core of the vortex, in the lower stratosphere), where minimum ozone mixing ratios are reached (Solomon et al., 2005), we suggest the following picture of Antarctic ozone depletion. First, as the initial step of chlorine activation, the available $\mathrm{ClONO}_{2}$ is titrated against $\mathrm{HCl}$ via Reaction (R1). Then, very little chemical change occurs in polar night until early August ("sleeping chemistry") and a relatively slow additional chlorine activation until early September. The maintenance of high $\mathrm{ClO}_{x}$ values during mid-September to early October is accomplished by effective reaction cycles (" $\mathrm{HCl}$ null cycles") which chemically inhibit a deactivation of chlorine that would otherwise proceed via net $\mathrm{HCl}$ formation. The period mid-September to early October is the period during which most of the Antarctic ozone loss occurs. This period of high $\mathrm{ClO}_{x}$ ends abruptly with the rapid formation of $\mathrm{HCl}$ leading to deactivation of chlorine (Grooß et al., 1997, 2011).

We present box-model calculations of Antarctic chlorine chemistry and ozone depletion which allow the chemical mechanisms and the impact of particular reactions to be studied in detail. In particular, we apply a detailed analysis of the temporal development of the rates of the key chemical processes based on a unique algorithm for the determination of chemical pathways (Lehmann, 2004). We demonstrate that for the efficacy of the $\mathrm{HCl}$ null cycles it is essential that the heterogeneous reaction (Prather, 1992; Crutzen et al., 1992)

$\mathrm{HOCl}+\mathrm{HCl} \rightarrow \mathrm{Cl}_{2}+\mathrm{H}_{2} \mathrm{O}$

and the gas-phase reaction (Crutzen et al., 1992)

$\mathrm{CH}_{3} \mathrm{O}_{2}+\mathrm{ClO} \rightarrow \mathrm{CH}_{3} \mathrm{O}+\mathrm{ClOO}$

(where the product $\mathrm{ClOO}$ decomposes rapidly to $\mathrm{Cl}$ and $\mathrm{O}_{2}$ ) occur. Further, the related formation of $\mathrm{HO}_{x}$ radicals from $\mathrm{CH}_{3} \mathrm{O}$ is important.

\section{Methods}

\subsection{Model description}

The simulations presented here were performed with the Chemical Lagrangian model of the Stratosphere (McKenna et al., 2002; Grooß et al., 2005) (CLaMS); the setup follows closely one used earlier (Grooß et al., 2011; Zafar, 2016). The model is used in box-model mode, where stratospheric chemistry is calculated for air parcels along threedimensional trajectories. The air parcels are defined by the location and time of minimum ozone soundings in the ozone hole period, from which trajectories are calculated both backward to June and forward to December. In this way, trajectories from the core of the vortex in the lower stratosphere are selected. The trajectories of the air parcels were calculated using wind and temperature data from operational analyses from the European Centre for Medium-Range Weather Forecasts (ECMWF). The latitudinal range covered by the trajectory in June, July, and August is roughly 60 to $80^{\circ} \mathrm{S}$, in September roughly 70 to $90^{\circ} \mathrm{S}$, and in October and November roughly 60 to $85^{\circ} \mathrm{S}$. The diabatic descent rates were calculated using a radiation code (Morcrette, 1991; Zhong and Haigh, 1995) assuming a cloud-free atmosphere. We use temperatures from the ECMWF operational analyses and climatological ozone and water vapour profiles (Grooß and Russell III, 2005).

The initial values for the main trace gases at the start of the simulation ( 1 June 2003) are $\mathrm{O}_{3}=2.2 \mathrm{ppm}$, $\mathrm{H}_{2} \mathrm{O}=4.1 \mathrm{ppm}, \quad \mathrm{CH}_{4}=1.2 \mathrm{ppm}, \quad \mathrm{HNO}_{3}=4.5 \mathrm{ppb}$, $\mathrm{HCl}=1.05 \mathrm{ppb}, \quad \mathrm{ClO}_{x}=1.01 \mathrm{ppb}, \quad \mathrm{ClONO}_{2}=12 \mathrm{ppt}$, $\mathrm{HOCl}=5 \mathrm{ppt}, \mathrm{Br}_{y}=17 \mathrm{ppt}$, and $\mathrm{CO}=16 \mathrm{ppb}$. The sensitivity of the results of the simulations on the initial ozone mixing ratio is discussed in the appendix. (All these values are given in molar mixing ratios; throughout this paper we use molar / volume mixing ratios.)

In Antarctic winter, temperatures typically fall below the threshold for chlorine activation and for the occurrence of polar stratospheric clouds (PSCs) approximately in mid-May (Pitts et al., 2009). Consistently, the initial values for chlorine species assumed here imply that the initial titration of $\mathrm{HCl}$ and $\mathrm{ClONO}_{2}$ (Reaction R1) has already occurred by 1 June. (The term titration is used here in the sense that in a reaction one of the reactants, here $\mathrm{ClONO}_{2}$, is completely used up.) Likewise, the initial value assumed for $\mathrm{HNO}_{3}$ implies that denitrification through the sedimentation of large NAT (nitric acid trihydrate) particles (e.g. Fahey et al., 2001; Molleker et al., 2014; Grooß et al., 2014) had occurred by this time. This assumption likely constitutes a slightly too early onset of denitrification, but the impact of this assumption is minimal during polar night. The impact of denitrification has been explored in sensitivity studies (see the Appendix).

To integrate the system of stiff ordinary differential equations describing the chemistry we employ the solver SVODE (Brown et al., 1989), which does not use the family approx- 
imation. The chemical kinetic data are taken from Sander et al. (2011). The photolysis rates are calculated in spherical geometry (Becker et al., 2000) for every hour using a climatological ozone profile for ozone hole conditions from HALOE measurements (Grooß and Russell III, 2005).

Of particular importance for the simulations discussed here is the representation of the photolysis of $\mathrm{CH}_{2} \mathrm{O}$. We have employed the recommended setup for both cross sections and quantum yields for $223 \mathrm{~K}$ (Sander et al., 2011). Using the photolysis quantum yields suggested by Röth and Ehhalt (2015) produces very similar results to those presented here (Zafar, 2016).

The branching ratios for the two channels (molecular channel and radical channel) of the photolysis of $\mathrm{CH}_{2} \mathrm{O}$ are uncertain; an estimate of the uncertainty, including possible line structures, is about $\pm 20 \%$ for the radical channel (Fig. 1 in Röth and Ehhalt, 2015). In a sensitivity study, we also employ branching ratios of 0 and $100 \%$, which cannot occur in reality (Röth and Ehhalt, 2015). They are used here as lower and upper limits. A possible temperature dependence of both the cross sections and the quantum yields of the photolysis of $\mathrm{CH}_{2} \mathrm{O}$ could be important, as it could potentially lead to a different production of $\mathrm{HO}_{2}$ in the photolysis of $\mathrm{CH}_{2} \mathrm{O}$ for the temperature range below $200 \mathrm{~K}$ relevant here. The intensities of the maxima of each absorption band increase with lower temperatures, but an accurate temperature dependence of these kinetic data for temperatures in the polar lower stratosphere cannot be considered here due to a lack of laboratory information (Smith et al., 2006; Röth and Ehhalt, 2015).

Heterogeneous chemistry is calculated on ice, NAT, liquid ternary particles $\left(\mathrm{H}_{2} \mathrm{SO}_{4} / \mathrm{H}_{2} \mathrm{O} / \mathrm{HNO}_{3}\right)$, and cold liquid binary aerosols. Temperature dependent uptake coefficients of heterogeneous reactions on liquid ternary and binary aerosols are taken from parametrisations by Shi et al. (2001) as recommended (Sander et al., 2011). For uptake coefficients for reactions on NAT the parametrisation of Carslaw and Peter (1997) is used, based on laboratory measurements of Hanson and Ravishankara (1993). NAT particles are assumed to form from supercooled ternary solution (STS) droplets. $\mathrm{A} \mathrm{HNO}_{3}$ supersaturation of three (corresponding to about $10 \mathrm{~K}$ supercooling) is required for NAT formation. The NAT particle density is assumed to be $3 \times 10^{-3} \mathrm{~cm}^{-3}$. This NAT particle density is lower than assumed by Grooß et al. (2011) leading to a greater impact of the reactivity on liquid particles in the simulations presented here.

\subsection{Pathway analysis}

A pathway in a chemical reaction system is a set of reactions converting some reactants of interest into some products of interest through some intermediate species, for which no net production or destruction occurs. An integer factor ("multiplicity") may be assigned to each reaction. The algorithm used here for the automatic determination of all significant pathways in a chemical reaction system was developed by Lehmann (2004). As input it requires a set of chemical reaction equations and reaction rates, which are usually provided by a chemical model. Starting from the individual reactions (and their rates) as initial pathways, longer pathways are constructed step by step by connecting shorter ones. If a newly formed pathway contains sub-pathways, it is split into these. A rate for each pathway is calculated. Pathways with rates below a pre-described threshold are deleted already during the construction process, in order to avoid an intractably large number of pathways ("combinatorial explosion").

\section{Results}

\subsection{Maintenance of chlorine activation}

We conducted box-model simulations for which the impact of mixing is neglected; however mixing across the Antarctic vortex edge is frequently overestimated substantially in current chemistry climate models (Hoppe et al., 2014). For the box model, the development of temperature, potential temperature and solar zenith angle along a typical air parcel trajectory in Antarctic spring is shown in Fig. 1a-c. The initial titration between $\mathrm{HCl}$ and $\mathrm{ClONO}_{2}$ via Reaction (R1) occurred before June (as usually in the Antarctic; e.g. Santee et al., 2008) so that the model simulation starts with about $1 \mathrm{ppb}$ of $\mathrm{ClO}_{x}$ and with near-zero values of $\mathrm{ClONO}_{2}$. Little further chemical change occurs ("sleeping chemistry") as long as solar zenith angles are large (until end of July), but with decreasing solar zenith angle, $\mathrm{HCl}$ further decreases, leading to increasing $\mathrm{ClO}_{x}$ and, subsequently, chemical ozone destruction (e.g. Salawitch et al., 1988; Santee et al., 2005, 2008; Grooß et al., 2011). Ozone decreases most rapidly in September and reaches minimum values of less than 20 ppb on 24 September (for the specific case considered here).

With decreasing ozone, the $\mathrm{Cl} / \mathrm{ClO}$ ratio shifts increasingly towards $\mathrm{Cl}$ (Douglass et al., 1995; Grooß et al., 1997), so that $\mathrm{HCl}$ production via the reactions of $\mathrm{Cl}$ with $\mathrm{CH}_{4}$ and $\mathrm{CH}_{2} \mathrm{O}$ (Reactions $\mathrm{R} 4$ and R11) increases substantially by more than an order of magnitude between the end of August and the end of September (Fig. $1 \mathrm{~g}$ ). Indeed, $\mathrm{HCl}$ formation through Reaction (R4) is commonly considered as the main chlorine deactivation mechanism in Antarctic spring.

The formation rate of $\mathrm{HCl}$ via Reactions (R4) and (R11) at the end of September amounts to more than $0.5 \mathrm{ppb}$ per day. If these reactions proceeded unbalanced, chlorine activation and thus ozone depletion would be stopped within days. However, using an algorithm for the determination of chemical pathways (Lehmann, 2004) cycles C1 and C2 are identified for this period: 


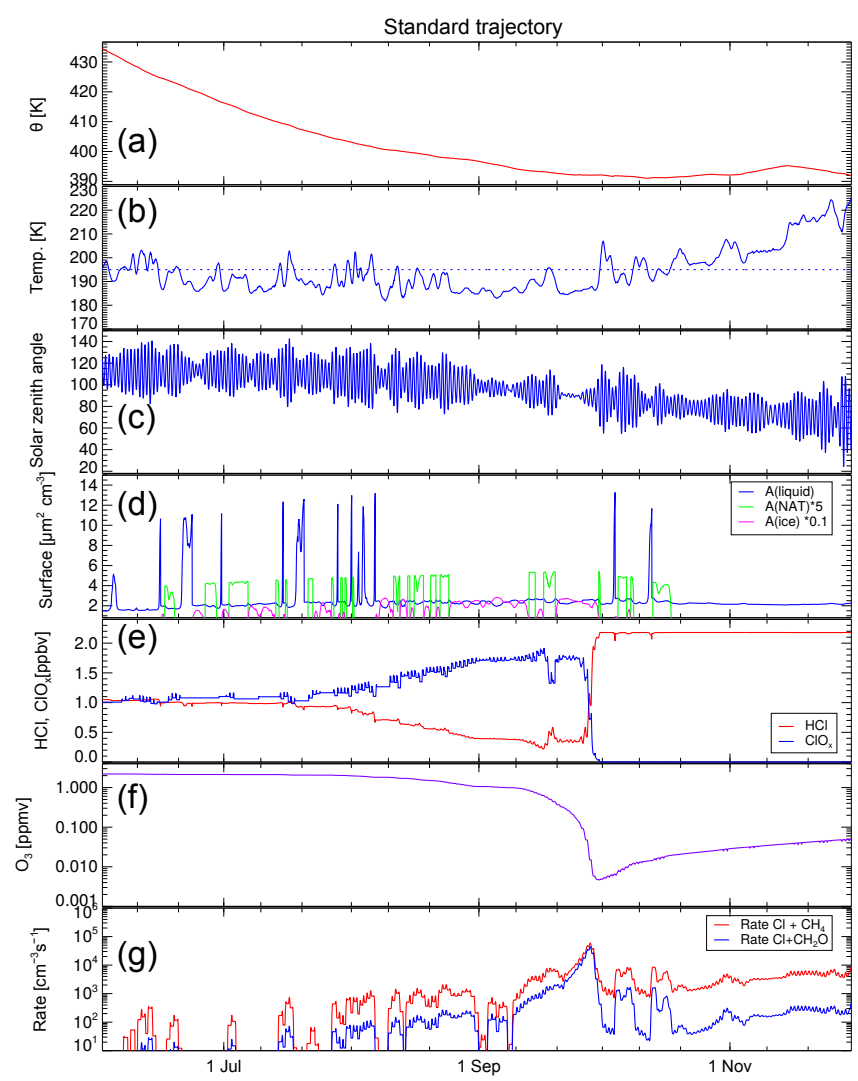

Figure 1. Box-model simulations along a trajectory passing through the location of the ozone sonde observation at South Pole of $14 \mathrm{ppb}$ on $74 \mathrm{hPa}(391 \mathrm{~K})$ on 24 September 2003 (Grooß et al., 2011). The different panels show a time series of the relevant parameters: (a) potential temperature of the air parcel, (b) temperature, (c) solar zenith angle, (d) surface area density of ice (red, scaled by 0.1), NAT (green, scaled by 5) and liquid aerosol particles (blue), (e) $\mathrm{ClO}_{x}$ (blue) and $\mathrm{HCl}$ (red), (f) ozone, and (g) rates of reaction of atomic chlorine with $\mathrm{CH}_{4}$ (blue) and $\mathrm{CH}_{2} \mathrm{O}$ (red). For reasons of clarity, the reaction rates in panel (g) are plotted as $24 \mathrm{~h}$ running averages. The model simulation covers the time period from 1 June to 30 November 2003.

$$
\begin{aligned}
\mathrm{CH}_{4}+\mathrm{Cl} & \rightarrow \mathrm{HCl}+\mathrm{CH}_{3}, \\
\mathrm{CH}_{3}+\mathrm{O}_{2}+M & \rightarrow \mathrm{CH}_{3} \mathrm{O}_{2}+M, \\
\mathrm{CH}_{3} \mathrm{O}_{2}+\mathrm{ClO} & \rightarrow \mathrm{CH}_{3} \mathrm{O}+\mathrm{Cl}+\mathrm{O}_{2}, \\
\mathrm{CH}_{3} \mathrm{O}+\mathrm{O}_{2} & \rightarrow \mathrm{HO}_{2}+\mathrm{CH}_{2} \mathrm{O}, \\
\mathrm{ClO}+\mathrm{HO}_{2} & \rightarrow \mathrm{HOCl}+\mathrm{O}_{2}, \\
\mathrm{HOCl}+\mathrm{HCl} & \rightarrow \mathrm{Cl}_{2}+\mathrm{H}_{2} \mathrm{O}, \\
\mathrm{Cl}_{2}+\mathrm{h} v & \rightarrow 2 \mathrm{Cl}, \\
\mathrm{Cl}+\mathrm{O}_{3} & \rightarrow \mathrm{ClO}+\mathrm{O}_{2} \quad(2 \times),
\end{aligned}
$$

$\operatorname{Net}(\mathrm{C} 1): \quad \mathrm{CH}_{4}+2 \mathrm{O}_{3} \rightarrow \mathrm{CH}_{2} \mathrm{O}+\mathrm{H}_{2} \mathrm{O}+2 \mathrm{O}_{2}$.

Cycle C1 was first formulated by Crutzen et al. (1992), demonstrating the importance of Reaction (R3) for ozone hole chemistry. Reaction (R3) is essential for the production of a $\mathrm{HO}_{2}$ radical from the $\mathrm{CH}_{3}$ formed in Reaction (R4).

$$
\begin{aligned}
\mathrm{CH}_{2} \mathrm{O}+\mathrm{Cl} & \rightarrow \mathrm{HCl}+\mathrm{CHO} \\
\mathrm{CHO}+\mathrm{O}_{2} & \rightarrow \mathrm{CO}+\mathrm{HO}_{2} \\
\mathrm{ClO}+\mathrm{HO}_{2} & \rightarrow \mathrm{HOCl}+\mathrm{O}_{2} \\
\mathrm{HOCl}+\mathrm{HCl} & \rightarrow \mathrm{Cl}_{2}+\mathrm{H}_{2} \mathrm{O} \\
\mathrm{Cl}_{2}+\mathrm{h} v & \rightarrow 2 \mathrm{Cl} \\
\mathrm{Cl}+\mathrm{O}_{3} & \rightarrow \mathrm{ClO}+\mathrm{O}_{2}
\end{aligned}
$$$$
\text { Net(C2) : } \quad \mathrm{CH}_{2} \mathrm{O}+\mathrm{O}_{3} \rightarrow \mathrm{CO}+\mathrm{H}_{2} \mathrm{O}+\mathrm{O}_{2}
$$

In cycles $\mathrm{C} 1$ and $\mathrm{C} 2, \mathrm{HOCl}$ is produced at the same rate as $\mathrm{HCl}$ because in both Reactions (R4) and (R11), for each $\mathrm{HCl}$ molecule produced, an $\mathrm{HO}_{2}$ radical is also generated (from $\mathrm{CH}_{3}$ via Reactions $\mathrm{R} 5, \mathrm{R} 3$, and $\mathrm{R} 6$ or from $\mathrm{CHO}$ via R12). This $\mathrm{HO}_{2}$ radical reacts further to form $\mathrm{HOCl}$, which then reacts heterogeneously with $\mathrm{HCl}$ (in Reaction $\mathrm{R} 2$ ) so that there is no net production of $\mathrm{HCl}$. We therefore refer to cycles $\mathrm{C} 1$ and $\mathrm{C} 2$ in the following as " $\mathrm{HCl}$ null cycles".

For the $\mathrm{HCl}$ null-cycle argument it is essential that Reaction (R3) dominates the loss of $\mathrm{CH}_{3} \mathrm{O}_{2}$, and indeed alternative reactions for $\mathrm{CH}_{3} \mathrm{O}_{2}$ (e.g. the $\mathrm{CH}_{3} \mathrm{O}_{2}$ self-reaction) were discussed (Müller and Crutzen, 1994). However, all relevant alternative reactions are included in the chemical scheme used here and the competition of the different reaction pathways of $\mathrm{CH}_{3} \mathrm{O}_{2}$ is addressed in the pathway analysis that was employed (Lehmann, 2004).

These $\mathrm{HCl}$ null cycles are effective in ensuring that there is no net production of $\mathrm{HCl}$ even though the speed of Reactions (R4) and (R11), and thus the production of $\mathrm{HCl}$, increases by about 2 orders of magnitude during September (Fig. 1g).

We find that during the first 10 days of September, $\mathrm{HCl}$ is recycled at a slow rate of $88 \mathrm{ppt}$ in 10 days through cycle $\mathrm{C} 1$, at a rate of $26 \mathrm{ppt}$ in 10 days through cycle $\mathrm{C} 2$. However, for the last days of September (21-30), the rate of recycling of $\mathrm{HCl}$ in cycles $\mathrm{C} 1$ and $\mathrm{C} 2$ is much more rapid; the rates are $3.7 \mathrm{ppb}$ in 10 days and $2.9 \mathrm{ppb}$ in 10 days respectively.

Thus cycles $\mathrm{C} 1$ and $\mathrm{C} 2$ constitute the chemical mechanism responsible for the maintenance of high levels of active chlorine (and thus of continued ozone destruction) under conditions of increasingly rapid $\mathrm{HCl}$ formation in Reactions (R4) and (R11).

\subsection{The path to full activation of $\mathrm{HCl}$}

As cycles $\mathrm{C} 1$ and $\mathrm{C} 2$ are $\mathrm{HCl}$ null cycles, they cannot explain the decrease in $\mathrm{HCl}$ from values of $\approx 1 \mathrm{ppb}$ in early July to very low values (about $0.2 \mathrm{ppb}$ ) during late August and September and thus the complete activation of chlorine as observed (Santee et al., 2008).

Using the pathway analysis (Lehmann, 2004), we identify two chemical cycles, C3 and C4, which are responsible for 
the decline of $\mathrm{HCl}$ during August and September:

$$
\begin{aligned}
\mathrm{CH}_{2} \mathrm{O}+\mathrm{h} v & \rightarrow \mathrm{CHO}+\mathrm{H}, \\
\mathrm{H}+\mathrm{O}_{2}+M & \rightarrow \mathrm{HO}_{2}+M, \\
\mathrm{CHO}+\mathrm{O}_{2} & \rightarrow \mathrm{CO}+\mathrm{HO}_{2}, \\
\mathrm{ClO}+\mathrm{HO}_{2} & \rightarrow \mathrm{HOCl}+\mathrm{O}_{2}
\end{aligned}
$$

$$
\begin{aligned}
\mathrm{HOCl}+\mathrm{HCl} & \rightarrow \mathrm{Cl}_{2}+\mathrm{H}_{2} \mathrm{O} \quad(2 \times), \\
\mathrm{Cl}_{2}+\mathrm{h} v & \rightarrow 2 \mathrm{Cl} \quad(2 \times), \\
\mathrm{Cl}+\mathrm{O}_{3} & \rightarrow \mathrm{ClO}+\mathrm{O}_{2} \quad(4 \times),
\end{aligned}
$$

$\operatorname{Net}(\mathrm{C} 3): \quad \mathrm{CH}_{2} \mathrm{O}+2 \mathrm{HCl}+4 \mathrm{O}_{3} \rightarrow \mathrm{CO}+2 \mathrm{ClO}+2 \mathrm{H}_{2} \mathrm{O}$ $+4 \mathrm{O}_{2}$

$$
\begin{aligned}
\mathrm{O}_{3}+\mathrm{h} v & \rightarrow \mathrm{O}\left({ }^{1} \mathrm{D}\right)+\mathrm{O}_{2}, \\
\mathrm{O}\left({ }^{1} \mathrm{D}\right)+\mathrm{H}_{2} \mathrm{O} & \rightarrow 2 \mathrm{OH}, \\
\mathrm{OH}+\mathrm{O}_{3} & \rightarrow \mathrm{HO}_{2}+\mathrm{O}_{2} \quad(2 \times), \\
\mathrm{ClO}+\mathrm{HO}_{2} & \rightarrow \mathrm{HOCl}+\mathrm{O}_{2} \quad(2 \times), \\
\mathrm{HOCl}+\mathrm{HCl} & \rightarrow \mathrm{Cl}_{2}+\mathrm{H}_{2} \mathrm{O} \quad(2 \times), \\
\mathrm{Cl}_{2}+\mathrm{h} v & \rightarrow 2 \mathrm{Cl} \quad(2 \times), \\
\mathrm{Cl}+\mathrm{O}_{3} & \rightarrow \mathrm{ClO}+\mathrm{O}_{2} \quad(4 \times),
\end{aligned}
$$

$\mathrm{Net}(\mathrm{C} 4): \quad 2 \mathrm{HCl}+7 \mathrm{O}_{3} \rightarrow 2 \mathrm{ClO}+\mathrm{H}_{2} \mathrm{O}+9 \mathrm{O}_{2}$.

Reaction (R19) may also proceed in two steps:

$$
\begin{aligned}
\mathrm{OH}+\mathrm{ClO} & \rightarrow \mathrm{HO}_{2}+\mathrm{Cl}, \\
\mathrm{Cl}+\mathrm{O}_{3} & \rightarrow \mathrm{ClO}+\mathrm{O}_{2},
\end{aligned}
$$

Net : $\quad \mathrm{OH}+\mathrm{O}_{3} \rightarrow \mathrm{HO}_{2}+\mathrm{O}_{2}$.

First, both cycles $\mathrm{C} 3$ and $\mathrm{C} 4$ require sufficiently fast heterogeneous reactions to be present. Second, in both cycles, it is important that $\mathrm{HO}_{2}$ radicals are produced without simultaneous $\mathrm{HCl}$ formation (in contrast to cycles $\mathrm{C} 1$ and $\mathrm{C} 2$ ). The $\mathrm{HO}_{2}$ radicals lead to formation of $\mathrm{HOCl}$ so that there is net $\mathrm{HCl}$ loss through Reaction (R2). The formation of $\mathrm{HO}_{2}$ radicals in $\mathrm{C} 3$ and $\mathrm{C} 4$ is thus the key process responsible for the decline of $\mathrm{HCl}$ in August and September.

Reactions (R9), (R17), and (R19) are fast enough to sustain cycles $\mathrm{C} 3$ and $\mathrm{C} 4$ even at the very low ozone concentrations as they occur in late September. For example, in the reference run for 26 September, the diurnal mean ozone mixing ratio is $77 \mathrm{ppb}$, the rate of Reaction (R9) is $46 \mathrm{ppb} \mathrm{d}^{-1}$, the rate of Reaction (R17) is $15 \mathrm{ppb} \mathrm{d}^{-1}$, and the net rate of Reaction (R19) is $3.2 \times 10^{-2} \mathrm{ppb} \mathrm{d}^{-1}$ directly and $1.1 \mathrm{ppb} \mathrm{d}^{-1}$ when it proceeds in two steps (Reactions R21 and R9). A turnover of $46 \mathrm{ppb}$ in Reaction (R9) in 1 day exceeds the available chlorine by more than an order of magnitude. This means that the available chlorine is cycled more than 10 times per day through Reaction (R9). Therefore, even at extremely low ozone concentrations in late September, the rates of Reactions (R9), (R17), and (R19) are not rate-limiting for cycles $\mathrm{C} 3$ and $\mathrm{C} 4$. Under these conditions, the rate-limiting reaction for cycle $\mathrm{C} 3$ is the radical channel of the photolysis of $\mathrm{CH}_{2} \mathrm{O}$ (R14) and for cycle $\mathrm{C} 4$ the reaction of $\mathrm{O}\left({ }^{1} \mathrm{D}\right)$ with water vapour (R18). (Note that Reactions R9 and R17 do not constitute the rate-limiting step of ozone loss cycles and can therefore not be used to deduce the ozone loss rate.)

The dominant source of $\mathrm{HO}_{x}$ radicals under the conditions of the polar lower stratosphere in late winter and early spring is not the production of $\mathrm{O}\left({ }^{1} \mathrm{D}\right)$ radicals through ozone photolysis with subsequent reaction with $\mathrm{H}_{2} \mathrm{O}$, but rather the radical channel of the photolysis of $\mathrm{CH}_{2} \mathrm{O}$ (Reaction R14) (Crutzen et al., 1992; Müller and Crutzen, 1994; Crowley et al., 1994). Thus, the photolysis of $\mathrm{CH}_{2} \mathrm{O}$ (radical channel) is effectively driving the depletion of $\mathrm{HCl}$. In the time frame 20-31 August, $66 \%$ of the net $\mathrm{HCl}$ depletion occurs through the photolysis of $\mathrm{CH}_{2} \mathrm{O}$ and cycle $\mathrm{C} 3$ and only $15 \%$ through the formation of $\mathrm{O}\left({ }^{1} \mathrm{D}\right)$ and subsequent reaction with $\mathrm{H}_{2} \mathrm{O}$ (cycle C4). The rate of production of $\mathrm{ClONO}_{2}$, under the conditions considered here, is very low (see discussion below).

The photolysis of $\mathrm{CH}_{2} \mathrm{O}$ possesses two product channels; Reaction (R14) (radical channel) leading to the formation of two $\mathrm{HO}_{2}$ radicals and the molecular channel

$\mathrm{CH}_{2} \mathrm{O}+\mathrm{h} v \rightarrow \mathrm{CO}+\mathrm{H}_{2}$,

which does not lead to production of $\mathrm{HO}_{x}$. The branching ratio between Reactions (R14) and (R22) is uncertain; it is about $30 \%$ for the radical channel (Reaction R14) for the conditions in question here (Röth and Ehhalt, 2015; see also Sect. 2.1).

To demonstrate the importance of cycle $\mathrm{C} 3$ and in particular the $\mathrm{HO}_{2}$ production through Reactions (R14), (R15), and (R12) we conducted two sensitivity runs, one assuming $100 \%$ efficiency for radical channel Reaction (R22) and zero for the molecular channel Reaction (R10) (red line in Fig. 2) and vice versa (dark blue line in Fig. 2). These assumptions constitute upper and lower limits of $\mathrm{HO}_{2}$ production in Reactions (R14), (R15), and (R12) that will certainly not be reached in reality.

Assuming no $\mathrm{HO}_{2}$ production in the photolysis of $\mathrm{CH}_{2} \mathrm{O}$ (blue line in Fig. 2) leads to very little reduction in $\mathrm{HCl}$ between late August and late September. This corroborates the conclusion that, in this chemical scheme, the $\mathrm{HCl}$ depletion beyond the initial titration against $\mathrm{ClONO}_{2}$ is driven by the radical channel of the $\mathrm{CH}_{2} \mathrm{O}$ photolysis (R14). Assuming $100 \%$ efficiency for the $\mathrm{HO}_{2}$ producing channel in the $\mathrm{CH}_{2} \mathrm{O}$ photolysis (red line in Fig. 2) results in a much more rapid depletion of $\mathrm{HCl}$ than in the reference case and nearzero values of $\mathrm{HCl}$ are reached in late August. Consequently, in this case, values of $\mathrm{ClO}_{x}$ are higher and ozone destruction is faster. Minimum values of ozone are reached somewhat earlier and likewise the corresponding rapid increase (deactivation) of $\mathrm{HCl}$ occurs somewhat earlier.

A more realistic estimate of the experimental uncertainties of the branching ratio for the radical channel of the $\mathrm{CH}_{2} \mathrm{O}$ 


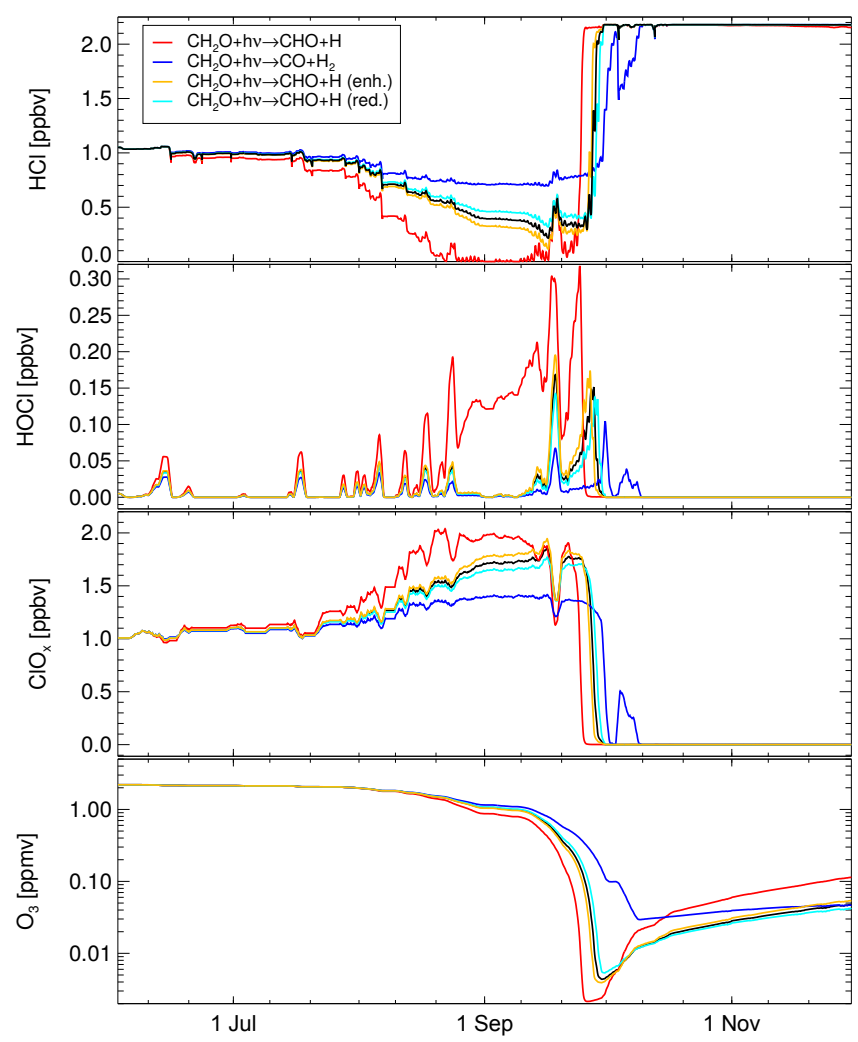

Figure 2. Sensitivity of the ozone hole chemistry on $\mathrm{HO}_{2}$ production in the photolysis of $\mathrm{CH}_{2} \mathrm{O}$. The black line shows the reference case, the red line a case assuming $100 \%$ efficiency for $\mathrm{HO}_{2}$ production (i.e. for Reaction R14), and the dark blue line a case assuming no $\mathrm{HO}_{2}$ production in the photolysis of $\mathrm{CH}_{2} \mathrm{O}(100 \%$ efficiency for Reaction R22). The light blue and the yellow line show a more realistic estimate of the kinetic uncertainties, namely branching ratio for the radical channel enhanced by $20 \%$ (yellow line) and reduced by $20 \%$ (light blue line).

photolysis is $\pm 20 \%$ (see Sect. 2.1). Results for this estimate are also shown in Fig. 2 (light blue and yellow lines). The results of this sensitivity test show enhanced $\mathrm{HCl}$ depletion for an enhanced radical channel (and reduced $\mathrm{HCl}$ depletion for a reduced radical channel), albeit to a much lower extent than for the upper and lower limit assumption.

During the period of near-zero values of $\mathrm{HCl}$ during late August to mid-September (in the case of a $100 \%$ radical channel) no substantial decrease in $\mathrm{ClO}_{x}$ and thus no deactivation through an increase in $\mathrm{HCl}$ occurs (red line in Fig. 2). This is the case because cycles $\mathrm{C} 1$ and C2 (net Reactions R10 and R13) are still active and prevent a net formation of $\mathrm{HCl}$. Solely the ongoing production of $\mathrm{HO}_{2}$ radicals causes somewhat enhanced levels of $\mathrm{HOCl}(0.1$ to $0.2 \mathrm{ppb}$ ) during this period. Photolysis of $\mathrm{HOCl}$ inhibits an accumulation of larger amounts of $\mathrm{HOCl}$.

\subsection{The role of $\mathrm{ClONO}_{2}$ and denitrification}

For the conditions in the heart of the ozone layer, in the lower stratosphere, which are considered here, reaction

$\mathrm{ClO}+\mathrm{NO}_{2}+M \rightarrow \mathrm{ClONO}_{2}+M$

and the related chemistry involving $\mathrm{ClONO}_{2}$ only play a minor role. This is the case mainly because PSCs consisting of NAT or STS exist almost continuously throughout the simulation sequestering most $\mathrm{HNO}_{3}$ from the gas phase. This leads to low $\mathrm{NO}_{2}$ concentrations even in the presence of sunlight in spring. Consequently, throughout Antarctic winter and spring, and in particular during the main ozone loss period from late August to late September, the rate of the heterogeneous reaction between $\mathrm{HCl}$ and $\mathrm{HOCl}$ (Reaction R2) is substantially larger than the rate of $\mathrm{HCl}+\mathrm{ClONO}_{2}(\mathrm{Re}-$ action $\mathrm{R} 1$ ), which is caused by the slow rate of formation of $\mathrm{ClONO}_{2}$. The $\mathrm{ClO}$ radical preferentially reacts with $\mathrm{HO}_{2}$ (forming $\mathrm{HOCl}$ ) rather than with $\mathrm{NO}_{2}$ (forming $\mathrm{ClONO}_{2}$ ).

For the efficacy of cycles $\mathrm{C} 1$ and $\mathrm{C} 2$, low gas-phase concentrations of $\mathrm{NO}_{2}$ (and thus of $\mathrm{HNO}_{3}$ ) are necessary. It is, however, not important whether the removal of $\mathrm{HNO}_{3}$ from the gas-phase occurs temporarily (uptake in particles) or permanently (denitrification). In our box-model simulations the impact of denitrification is taken into account by assuming that denitrification has occurred by the start of the simulation (4.5 ppb initial $\mathrm{HNO}_{3}$ at 1 June). Overall, for the conditions in the core of the Antarctic vortex considered here, there is very little impact of denitrification on ozone depletion (see the Appendix).

\subsection{Sensitivity of ozone loss on stratospheric methane and chlorine levels}

In the coming decades, the composition of the Antarctic lower stratosphere will change considerably; in particular, the stratospheric halogen loading will continue to decrease (e.g. WMO, 2014; Chipperfield et al., 2015). Repeating the reference run with $\mathrm{Cl}_{y}$ halved (blue line in Fig. 3) (typical conditions for $\approx 2050$ ) results in lower active chlorine $\mathrm{ClO}_{x}$ and thus slower ozone loss rates, as expected. However, in this case the ozone depletion period in the lower stratosphere is longer, so that extremely low ozone values (below $0.2 \mathrm{ppb}$ ) are reached also for the initial amount of $\mathrm{Cl}_{y}$ halved, albeit about 3 weeks later than in the reference case. The fact that in our simulation the impact of a reduced amount of $\mathrm{Cl}_{y}$ is mainly observed in September is consistent with the recent conclusion that signs of healing in the Antarctic ozone layer have emerged for September (Solomon et al., 2016). Note that in the reference case ozone depletion stops because ozone is reaching extremely low values although temperatures are still low enough for PSCs and heterogeneous processing; the same mechanism works for halved $\mathrm{Cl}_{y}$ - solely the low values are reached later in the season due to the slower ozone loss rate. 


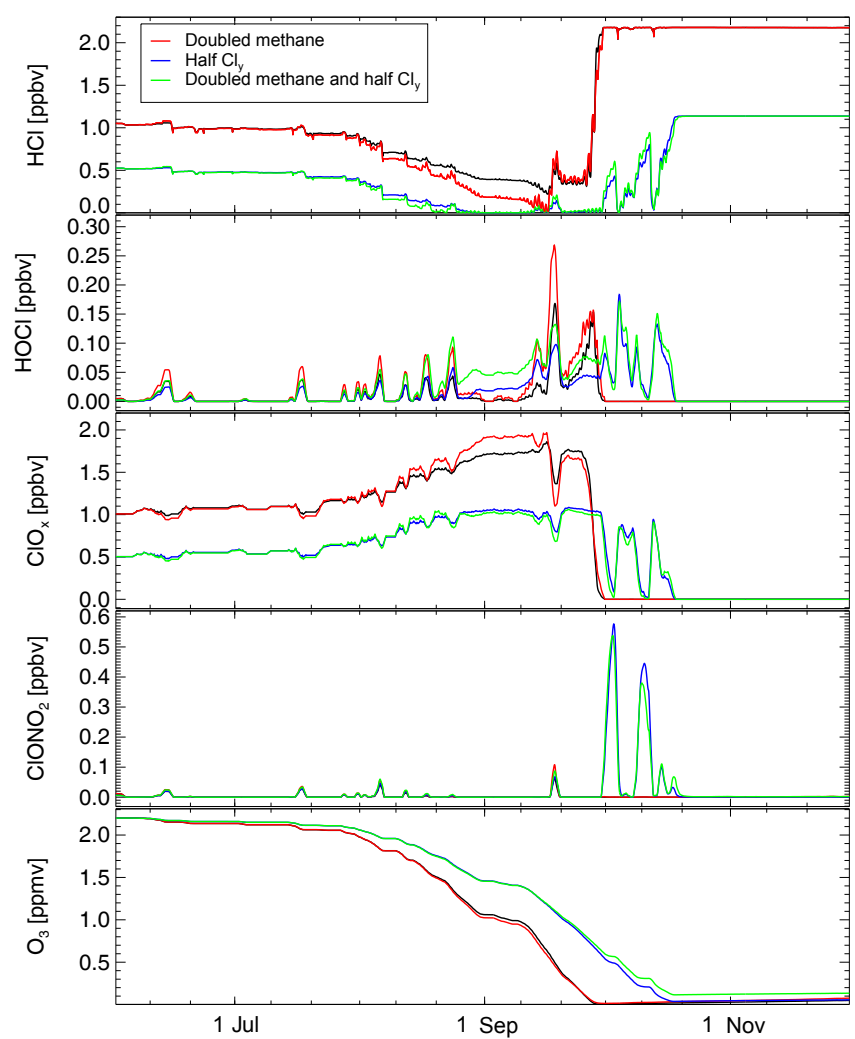

Figure 3. Sensitivity of the ozone hole chemistry on stratospheric methane and chlorine levels. The black line shows the reference case, the red line a case assuming initial methane to be doubled, the blue line a case assuming initial inorganic chlorine $\left(\mathrm{Cl}_{y}\right)$ to be halved, and the green line a case for initial methane doubled and $\mathrm{Cl}_{y}$ halved.

Doubling methane in the simulation leads to a speed-up of Reaction (R4), and thereby also to enhanced production of $\mathrm{CH}_{2} \mathrm{O}$ and thus also to a speed-up of Reaction (R11). But doubling methane does not lead to an enhanced deactivation, because cycles $\mathrm{C} 1$ and $\mathrm{C} 2$ are active and inhibit the deactivation effect of Reactions (R4) and (R11). However, surprisingly at first, doubling of methane means that more $\mathrm{CH}_{2} \mathrm{O}$ is produced in cycle $\mathrm{C} 1$, leading to somewhat faster $\mathrm{HCl}$ activation in late August and early September through cycle C3 and thus to higher $\mathrm{ClO}_{x}$ and a somewhat faster ozone depletion during this period.

A simulation combining doubled methane and halved $\mathrm{Cl}_{y}$ shows results very close to those for halved $\mathrm{Cl}_{y}$, but again the doubled methane does not lead to a substantially faster deactivation and practically the same very low ozone values are reached in late October. Thus we suggest that the very low ozone values observed today in the core of the polar vortex (Solomon et al., 2005) will continue to occur for decades to come and that the recovery of the stratospheric chlorine loading should lead to a shift by some weeks of the low val-

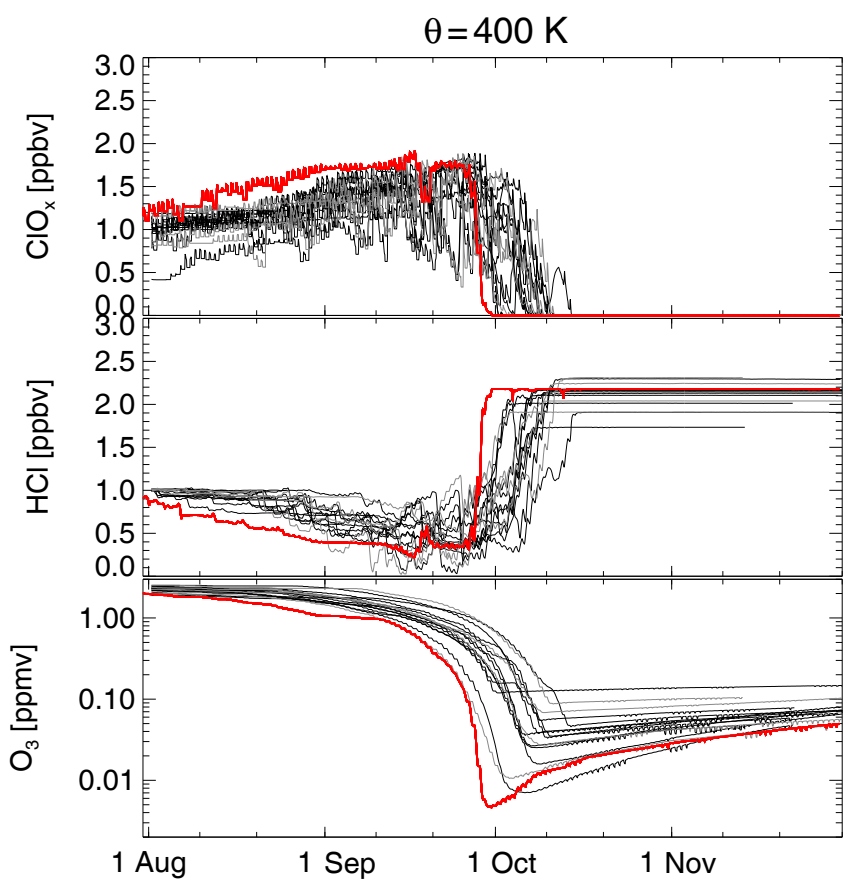

Figure 4. Results from multi-trajectory simulations of CLaMS. Box-model simulations were performed for a set of trajectories passing the South Pole at $400 \mathrm{~K}$ taken from Grooß et al. (2011). The box-model simulations cover the time period from 1 August to 30 November 2003. A few trajectories showing very little diabatic descent (and thus much smaller values of total chlorine) were neglected. Initial values were chosen consistently with the reference run (Fig. 1), which is shown here in red. Individual trajectories are shown in different shades of grey to allow them to be distinguished more easily.

ues to later in the season, consistent with recent observations (Solomon et al., 2016).

A feature only noticeable in the simulations for halved $\mathrm{Cl}_{y}$ is peaks of enhanced $\mathrm{ClONO}_{2}$ in late September and early October (Fig. 3). At this time, for halved $\mathrm{Cl}_{y}$, ozone is strongly reduced, but clearly higher than in the reference run and full deactivation has not occurred. During this time period, PSCs occasionally evaporate (owing to higher temperatures, Fig. 1), releasing $\mathrm{HNO}_{3}$ to the gas phase. This enhanced $\mathrm{HNO}_{3}$ leads to the production of $\mathrm{NO}_{2}$ with subsequent formation of $\mathrm{ClONO}_{2}$, similar to the formation of $\mathrm{ClONO}_{2}$ in the Arctic in late winter and early spring in periods with higher temperatures when PSCs evaporate (e.g. Müller et al., 1994). However, as discussed above, for halved $\mathrm{Cl}_{y}$ extremely low ozone mixing ratios are reached (albeit later than in the reference case), so that the final chlorine deactivation in mid-October occurs through a rapid, practically complete conversion of active chlorine into $\mathrm{HCl}$ (Fig. 3). 


\subsection{Multi-trajectory simulations}

We have repeated the reference run using the CLaMS model (McKenna et al., 2002; Grooß et al., 2005) in box-model mode for multiple trajectories. We employ a set of realistic trajectories passing the South Pole at $400 \mathrm{~K}$ potential temperature (in late September/early October) including diabatic descent and latitude variations (taken from Grooß et al., 2011). In the period early August to early October all trajectories are subject to roughly the same diabatic descent of $\approx 10 \mathrm{~K}$, similar to the reference run. In this period, all trajectories show strong variations in latitude, again similar as for the reference run. The latitude varies between the South Pole and $\approx 65^{\circ} \mathrm{S}$ with some equatorward excursions to $\approx 60^{\circ} \mathrm{S}$ or, even more rarely, to $\approx 55^{\circ} \mathrm{S}$.

The initial values (for 1 August) of $\mathrm{HCl}$ and $\mathrm{ClO}_{x}$ were chosen consistently with the reference run. The results of these runs (Fig. 4) show a significant variability in the decline of $\mathrm{HCl}$ and the ozone loss rate, but all show a rather similar behaviour to the reference run (shown in red), namely very little chemical change in polar night until early August ("sleeping chemistry") and a relatively slow additional chlorine activation until early September. The period thereafter is characterised by the maintenance of high $\mathrm{ClO}_{x}$ values during mid-September to early October (due to cycles C1 and C2) accompanied by rapid ozone loss. This period of high $\mathrm{ClO}_{x}$ ends abruptly with the rapid formation of $\mathrm{HCl}$ (and thus chlorine deactivation), which occurs in a similar way for the individual trajectories in the time frame late September to early October.

\section{Conclusions}

For the heart of the ozone hole in the Antarctic lowermost stratosphere, formation of $\mathrm{HCl}$ through Reactions (R4) and (R11) is very rapid for enhanced chlorine levels, with the rate of $\mathrm{HCl}$ formation increasing by more than a factor of 10 during September. We have shown that high levels of active chlorine are maintained nonetheless, because the formation of $\mathrm{HCl}$ is balanced in very effective $\mathrm{HCl}$ null cycles, allowing rapid chemical destruction of ozone to proceed. Further, for the depletion of $\mathrm{HCl}$ to very low values, formation of $\mathrm{HO}_{2}$ is essential, with photolysis of $\mathrm{CH}_{2} \mathrm{O}$ being the major net source of $\mathrm{HO}_{2}$. Owing to the uptake of $\mathrm{HNO}_{3}$ in NAT and STS particles, $\mathrm{NO}_{x}$ chemistry and the formation of $\mathrm{ClONO}_{2}$ are of minor importance. Chlorine is finally deactivated when an imbalance in the null cycles occurs, leading to a rapid and almost complete conversion of the activated chlorine into $\mathrm{HCl}$, which is putting a halt to ozone depletion (Douglass et al., 1995; Grooß et al., 1997, 2011). An increase in methane in the future should not lead to a faster ozone recovery. These results are important for an assessment of the impact of chemical change to come in the Antarctic stratosphere on the future development of the ozone hole.

Data availability. The model results presented here can be obtained in electronic form (NetCDF files) from the corresponding author on request. 


\section{Appendix A: Sensitivity studies}

In this section we discuss the sensitivity of the simulated development of chlorine chemistry and ozone mixing ratios with respect to the initial ozone and $\mathrm{HNO}_{3}$ mixing ratios (similar as in Grooß et al., 2011).

\section{A1 Initial ozone mixing ratio}

We conducted three additional box-model simulations, identical to the reference run (initial ozone $2.2 \mathrm{ppm}$ ), but with different initial ozone mixing ratios ranging from 2.0 to $2.6 \mathrm{ppm}$ (Fig. A1). The simulations show both different minimum ozone mixing ratios and different times at which these minima are reached (consistent with the results of Grooß et al., 2011). Similarly, the timing of the rapid increase in $\mathrm{HCl}$ and chlorine deactivation is different for the different initial ozone mixing ratios (Fig. A1).

Importantly, however, the general pattern of chlorine activation and decrease in $\mathrm{HCl}$ is very similar until about 20 September, indicating that the efficacy of the $\mathrm{HCl}$ null cycles is not affected by the initial ozone mixing ratio.

\section{A2 Denitrification}

The formation of PSCs impacts polar chemistry by taking up $\mathrm{HNO}_{3}$ and thereby reducing $\mathrm{HNO}_{3}$ in the gas phase (Crutzen and Arnold, 1986; Toon et al., 1986; Salawitch et al., 1988). In the case of STS particles the reduction of gas-phase $\mathrm{HNO}_{3}$ lasts only as long as temperatures are low enough for the particles to exist, because the particles are too small to sediment significantly. Nitric acid trihydrate particles, however, can grow to large sizes allowing substantial sedimentation rates, so that $\mathrm{HNO}_{3}$ is removed from stratospheric air masses permanently (a process referred to as "denitrification"; Fahey et al., 2001; Molleker et al., 2014). Denitrification is observed regularly in the lower stratosphere in Antarctica and in cold winters in the Arctic (e.g. Davies et al., 2006; Santee et al., 2008; Grooß et al., 2014).

For the case considered here, PSCs that sequester $\mathrm{HNO}_{3}$ from the gas phase exist almost continuously until midSeptember (Fig. 1). Therefore, the gas-phase concentration of $\mathrm{HNO}_{3}$ during the period of chlorine activation, maintenance of active chlorine, and chemical ozone depletion are controlled by PSCs and not by denitrification.

Nonetheless, we conducted a sensitivity simulation initialised with half $(2.25 \mathrm{ppb})$ or twice $(9 \mathrm{ppb})$ the amount of initial $\mathrm{HNO}_{3}$ (Fig. A2). These assumptions result in practically the same ozone depletion in late September as in the reference case (Fig. A2). For mid-September, the simulation with 9 ppb initial $\mathrm{HNO}_{3}$ shows about $10 \%$ more active chlorine than the reference run and thus a somewhat more rapid ozone loss (ozone in mid-September $\approx 0.1 \mathrm{ppm}$ less than in the reference run). For half the initial $\mathrm{HNO}_{3}(2.25 \mathrm{ppb})$ the situation is reversed, but differences are even smaller.

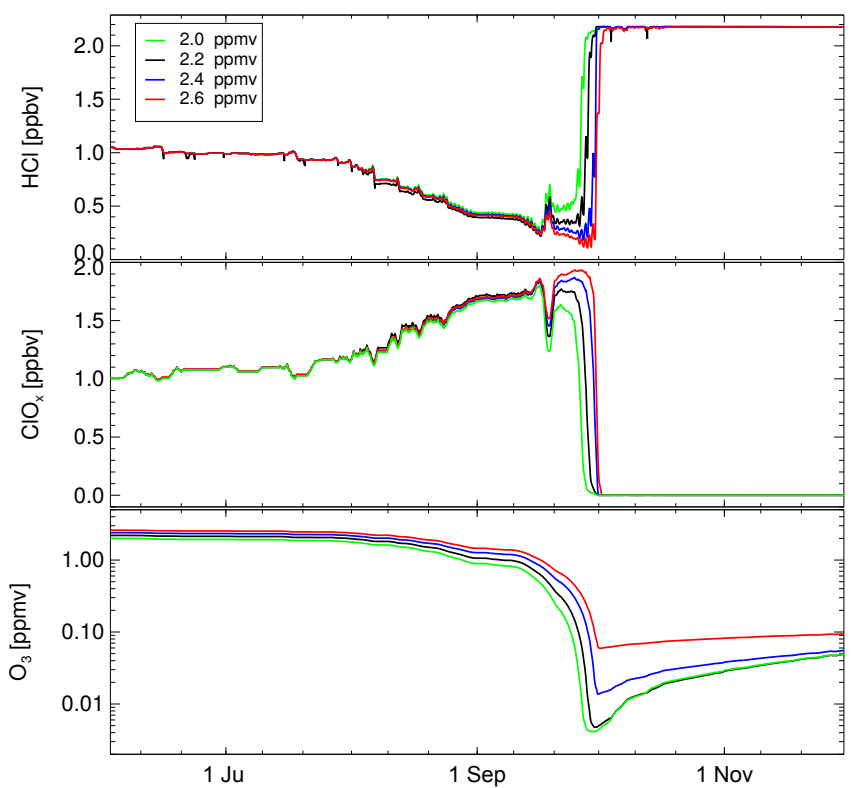

Figure A1. Simulations for different initial ozone mixing ratios. Simulation as in the reference run but with different initial ozone mixing ratios (2.0 to $2.6 \mathrm{ppm}$ ).

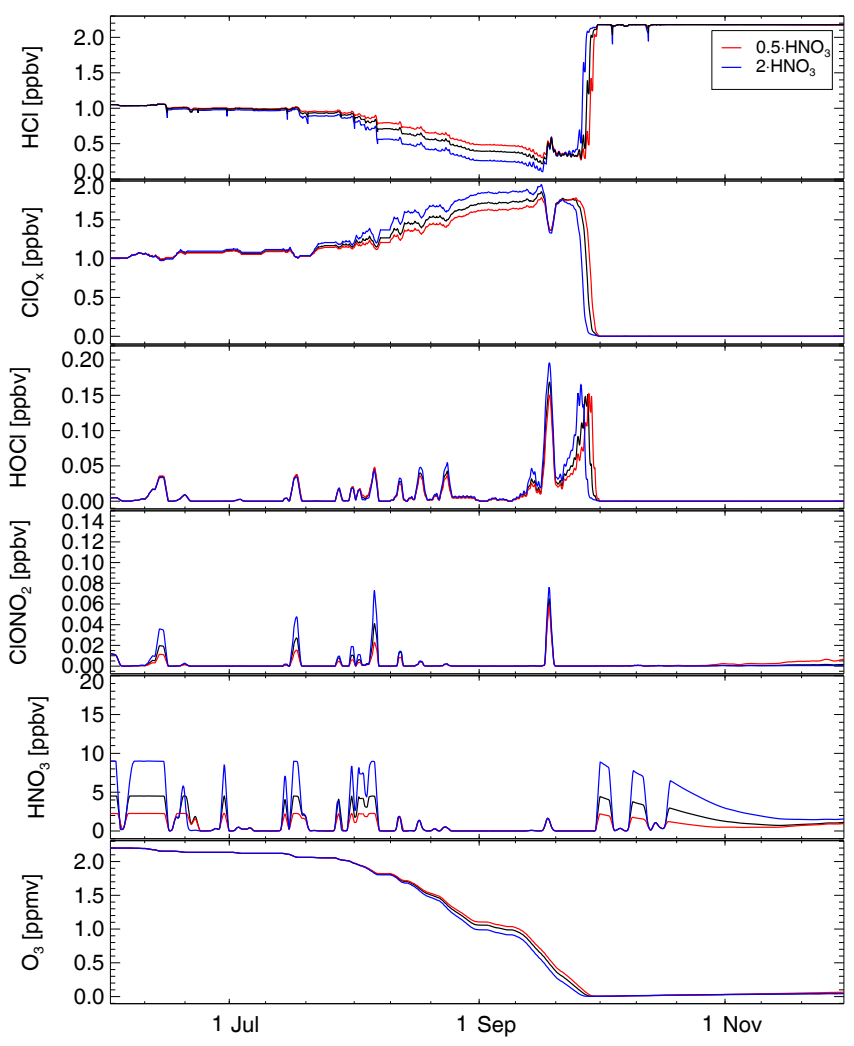

Figure A2. Simulation for the impact of denitrification. The impact of denitrification is tested by initialising the model run with $\mathrm{HNO}_{3}$ doubled (blue line) and halved (red line). The black line shows the results of the reference simulation. 
Thus, as to be expected, the impact of the initial $\mathrm{HNO}_{3}$ mixing ratio on the simulated ozone loss and chlorine activation is only moderate. Solely in the short periods when $\mathrm{HNO}_{3}$ is released to the gas phase and some of this gas-phase $\mathrm{HNO}_{3}$ is converted to $\mathrm{NO}_{x}$, the resulting production of $\mathrm{ClONO}_{2}$ is enhanced in the case of a greater initial $\mathrm{HNO}_{3}$ mixing ratio. Therefore, a greater initial $\mathrm{HNO}_{3}$ mixing ratio (assumption of no denitrification) leads to a somewhat faster $\mathrm{HCl}$ depletion (through Reaction R1), a stronger chlorine activation and thus somewhat more chemical ozone loss (Fig. A2).

Overall, like for the sensitivity on the initial ozone mixing ratio, the general pattern of chlorine activation and decrease in $\mathrm{HCl}$ is very similar for the results of the reference run and the results under the (rather extreme) assumptions of reduced and enhanced denitrification (Fig. A2). 
Author contributions. RM, JUG, and RL conceived and designed the research project. AMZ, SR, and JUG conducted the simulations. RL performed the pathway analysis. RM, JUG, AMZ, SR, and RL contributed to the interpretation of the results and wrote the paper.

Competing interests. The authors declare that they have no competing financial interests.

Acknowledgements. Part of this work was done in the frame of the master's thesis of Abdul Mannan Zafar at the Technische Universität Darmstadt; we thank Martin Ebert for supervising the thesis. Part of this work was funded by the European Community's Seventh Framework Programme (FP7/2007-2013) in the frame of the StratoClim project (grant agreement no. 603557). We thank the European Centre for Medium-Range Weather Forecasts (ECMWF) for providing meteorological data sets. Finally, we thank the reviewers and the editor (Farahnaz Khosrawi) for helpful comments.

The article processing charges for this open-access

publication were covered by a Research

Centre of the Helmholtz Association.

Edited by: Farahnaz Khosrawi

Reviewed by: two anonymous referees

\section{References}

Becker, G., Grooß, J.-U., McKenna, D. S., and Müller, R.: Stratospheric photolysis frequencies: Impact of an improved numerical solution of the radiative transfer equation, J. Atmos. Chem., 37, 217-229, https://doi.org/10.1023/A:1006468926530, 2000.

Brown, P. N., Byrne, G. D., and Hindmarsh, A. C.: VODE: A variable coefficient ODE solver, SIAM J. Sci. Stat. Comput., 10, 1038-1051, 1989.

Carslaw, K. S. and Peter, T.: Uncertainties in reactive uptake coefficients for solid stratospheric particles -1 . Surface chemistry, Geophys. Res. Lett., 24, 1743-1746, 1997.

Chipperfield, M. P., Dhomse, S. S., Feng, W., McKenzie, R. L., Velders, G. J. M., and Pyle, J. A.: Quantifying the ozone and ultraviolet benefits already achieved by the Montreal Protocol, Nat. Commun., 6, 7233, https://doi.org/10.1038/ncomms8233, 2015.

Crowley, J. N., Helleis, F., Müller, R., Moortgat, G. K., Crutzen, P. J., and Orlando, J. J.: $\mathrm{CH}_{3} \mathrm{OCl}$ : UV/Vis absorption crosssections, J values and atmospheric significance, J. Geophys. Res., 99, 20683-20688, 1994.

Crutzen, P. J. and Arnold, F.: Nitric acid cloud formation in the cold Antarctic stratosphere: A major cause for the springtime "ozone hole", Nature, 342, 651-655, 1986.

Crutzen, P. J., Müller, R., Brühl, C., and Peter, T.: On the potential importance of the gas phase reaction $\mathrm{CH}_{3} \mathrm{O}_{2}+\mathrm{ClO} \rightarrow \mathrm{ClOO}+$ $\mathrm{CH}_{3} \mathrm{O}$ and the heterogeneous reaction $\mathrm{HOCl}+\mathrm{HCl} \rightarrow \mathrm{H}_{2} \mathrm{O}+\mathrm{Cl}_{2}$ in "ozone hole" chemistry, Geophys. Res. Lett., 19, 1113-1116, https://doi.org/10.1029/92GL01172, 1992.

Davies, S., Mann, G. W., Carslaw, K. S., Chipperfield, M. P., Remedios, J. J., Allen, G., Waterfall, A. M., Spang, R., and Toon,
G. C.: Testing our understanding of Arctic denitrification using MIPAS-E satellite measurements in winter 2002/2003, Atmos. Chem. Phys., 6, 3149-3161, https://doi.org/10.5194/acp-6-31492006, 2006.

Douglass, A. R., Schoeberl, M. R., Stolarski, R. S., Waters, J. W., Russell III, J. M., Roche, A. E., and Massie, S. T.: Interhemispheric differences in springtime production of $\mathrm{HCl}$ and $\mathrm{ClONO}_{2}$ in the polar vortices, J. Geophys. Res., 100, 13967-13978, 1995.

Fahey, D. W., Gao, R. S., Carslaw, K. S., Kettleborough, J., Popp, P. J., Northway, M. J., Holecek, J. C., Ciciora, S. C., McLaughlin, R. J., Thompson, T. L., Winkler, R. H., Baumgardner, D. G., Gandrud, B., Wennberg, P. O., Dhaniyala, S., McKinley, K., Peter, T., Salawitch, R. J., Bui, T. P., Elkins, J. W., Webster, C. R., Atlas, E. L., Jost, H., Wilson, J. C., Herman, R. L., Kleinböhl, A., and von König, M.: The detection of large $\mathrm{HNO}_{3}$-containing particles in the winter Arctic stratosphere, Science, 291, 1026-1031, 2001.

Fernandez, R. P., Kinnison, D. E., Lamarque, J.-F., Tilmes, S., and Saiz-Lopez, A.: Impact of biogenic very short-lived bromine on the Antarctic ozone hole during the 21st century, Atmos. Chem. Phys., 17, 1673-1688, https://doi.org/10.5194/acp-171673-2017, 2017.

Grooß, J.-U. and Russell III, J. M.: Technical note: A stratospheric climatology for $\mathrm{O}_{3}, \mathrm{H}_{2} \mathrm{O}, \mathrm{CH}_{4}, \mathrm{NO}_{x}, \mathrm{HCl}$ and $\mathrm{HF}$ derived from HALOE measurements, Atmos. Chem. Phys., 5, 2797-2807, https://doi.org/10.5194/acp-5-2797-2005, 2005.

Grooß, J.-U., Pierce, R. B., Crutzen, P. J., Grose, W. L., and Russell III, J. M.: Re-formation of chlorine reservoirs in southern hemisphere polar spring, J. Geophys. Res., 102, 13141-13152, https://doi.org/10.1029/96JD03505, 1997.

Grooß, J.-U., Günther, G., Müller, R., Konopka, P., Bausch, S., Schlager, H., Voigt, C., Volk, C. M., and Toon, G. C.: Simulation of denitrification and ozone loss for the Arctic winter 2002/2003, Atmos. Chem. Phys., 5, 1437-1448, https://doi.org/10.5194/acp5-1437-2005, 2005.

Grooß, J.-U., Brautzsch, K., Pommrich, R., Solomon, S., and Müller, R.: Stratospheric ozone chemistry in the Antarctic: what determines the lowest ozone values reached and their recovery?, Atmos. Chem. Phys., 11, 12217-12226, https://doi.org/10.5194/acp-11-12217-2011, 2011.

Grooß, J.-U., Engel, I., Borrmann, S., Frey, W., Günther, G., Hoyle, C. R., Kivi, R., Luo, B. P., Molleker, S., Peter, T., Pitts, M. C., Schlager, H., Stiller, G., Vömel, H., Walker, K. A., and Müller, R.: Nitric acid trihydrate nucleation and denitrification in the Arctic stratosphere, Atmos. Chem. Phys., 14, 1055-1073, https://doi.org/10.5194/acp-14-1055-2014, 2014.

Hanson, D. R. and Ravishankara, A. R.: Reaction of $\mathrm{ClONO}_{2}$ with $\mathrm{HCl}$ on NAT, NAD, and frozen sulfuric acid and hydrolysis of $\mathrm{N}_{2} \mathrm{O}_{5}$ and $\mathrm{ClONO}_{2}$ on frozen sulfuric acid, J. Geophys. Res., 98, 22931-22936, 1993.

Hoppe, C. M., Hoffmann, L., Konopka, P., Grooß, J.-U., Ploeger, F., Günther, G., Jöckel, P., and Müller, R.: The implementation of the CLaMS Lagrangian transport core into the chemistry climate model EMAC 2.40.1: application on age of air and transport of long-lived trace species, Geosci. Model Dev., 7, 2639-2651, https://doi.org/10.5194/gmd-7-2639-2014, 2014.

Jaeglé, L., Webster, C. R., May, R. D., Scott, D. C., Stimpfle, R. M., Kohn, D. W., Wennberg, P. O., Hanisco, T. F., Cohen, R. C., Proffitt, M. H., Kelly, K. K., Elkins, J., Baumgardner, 
D., Dye, J. E., Wilson, J. C., Pueschel, R. F., Chan, K. R., Salawitch, R. J., Tuck, A. F., Hovde, S. J., and Yung, Y. L.: Evolution and stoichiometry of heterogeneous processing in the Antarctic stratosphere, J. Geophys. Res., 102, 13235-13253, https://doi.org/10.1029/97JD00935, 1997.

Lehmann, R.: An algorithm for the determination of all significant pathways in chemical reaction systems, J. Atmos. Chem., 47, 4578, 2004.

Manney, G. L., Santee, M. L., Rex, M., Livesey, N. J., Pitts, M. C., Veefkind, P., Nash, E. R., Wohltmann, I., Lehmann, R., Froidevaux, L., Poole, L. R., Schoeberl, M. R., Haffner, D. P., Davies, J., Dorokhov, V., Gernandt, H., Johnson, B., Kivi, R., Kyrö, E., Larsen, N., Levelt, P. F., Makshtas, A., McElroy, C. T., Nakajima, H., Parrondo, M. C., Tarasick, D. W., von der Gathen, P., Walker, K. A., and Zinoviev, N. S.: Unprecedented Arctic ozone loss in 2011, Nature, 478, 469-475, https://doi.org/10.1038/nature10556, 2011.

McElroy, M. B., Salawitch, R. J., Wofsy, S. C., and Logan, J. A.: Antarctic ozone: Reductions due to synergistic interactions of chlorine and bromine, Nature, 321, 759-762, 1986.

McKenna, D. S., Grooß, J.-U., Günther, G., Konopka, P., Müller, R., Carver, G., and Sasano, Y.: A new Chemical Lagrangian Model of the Stratosphere (CLaMS): 2. Formulation of chemistry scheme and initialization, J. Geophys. Res., 107, 4256, https://doi.org/10.1029/2000JD000113, 2002.

Molina, L. T. and Molina, M. J.: Production of $\mathrm{Cl}_{2} \mathrm{O}_{2}$ from the selfreaction of the $\mathrm{ClO}$ radical, J. Phys. Chem., 91, 433-436, 1987.

Molleker, S., Borrmann, S., Schlager, H., Luo, B., Frey, W., Klingebiel, M., Weigel, R., Ebert, M., Mitev, V., Matthey, R., Woiwode, W., Oelhaf, H., Dörnbrack, A., Stratmann, G., Grooß, J.U., Günther, G., Vogel, B., Müller, R., Krämer, M., Meyer, J., and Cairo, F.: Microphysical properties of synoptic-scale polar stratospheric clouds: in situ measurements of unexpectedly large $\mathrm{HNO}_{3}$-containing particles in the Arctic vortex, Atmos. Chem. Phys., 14, 10785-10801, https://doi.org/10.5194/acp-14-107852014, 2014.

Morcrette, J.-J.: Radiation and cloud radiative properties in the European Centre for Medium-Range Weather Forecasts forecasting system, J. Geophys. Res., 96, 9121-9132, 1991.

Müller, R. and Crutzen, P. J.: On the relevance of the methane oxidation cycle to "ozone hole" chemistry, in: Ozone in the troposphere and stratosphere, edited by: Hudson, R. D., Proceedings of the Quadrennial Ozone Symposium 1992, 298-301, 1994.

Müller, R., Peter, T., Crutzen, P. J., Oelhaf, H., Adrian, G. P., v. Clarmann, T., Wegner, A., Schmidt, U., and Lary, D.: Chlorine chemistry and the potential for ozone depletion in the Arctic stratosphere in the winter of 1991/92, Geophys. Res. Lett., 21, 1427-1430, 1994.

Oman, L. D., Douglass, A. R., Salawitch, R. J., Canty, T. P., Ziemke, J. R., and Manyin, M.: The effect of representing bromine from VSLS on the simulation and evolution of Antarctic ozone, Geophys. Res. Lett., 43, 9869-9876, https://doi.org/10.1002/2016GL070471, 2016.

Pitts, M. C., Poole, L. R., and Thomason, L. W.: CALIPSO polar stratospheric cloud observations: second-generation detection algorithm and composition discrimination, Atmos. Chem. Phys., 9, 7577-7589, https://doi.org/10.5194/acp-9-7577-2009, 2009.

Portmann, R. W., Solomon, S., Garcia, R. R., Thomason, L. W., Poole, L. R., and McCormick, M. P.: Role of aerosol variations in anthropogenic ozone depletion in the polar regions, J. Geophys Res., 101, 22991-23006, 1996.

Prather, M. J.: More rapid ozone depletion through the reaction of $\mathrm{HOCl}$ with $\mathrm{HCl}$ on polar stratospheric clouds, Nature, 355, 534537, 1992.

Röth, E.-P. and Ehhalt, D. H.: A simple formulation of the $\mathrm{CH}_{2} \mathrm{O}$ photolysis quantum yields, Atmos. Chem. Phys., 15, 7195-7202, https://doi.org/10.5194/acp-15-7195-2015, 2015.

Salawitch, R. J., Wofsy, S. C., and McElroy, M. B.: Influence of polar stratospheric clouds on the depletion of Antarctic ozone, Geophys. Res. Lett., 15, 871-874, 1988.

Sander, S. P., Abbatt, J., Barker, J. R., Burkholder, J. B., Friedl, R. R., Golden, D. M., Huie, R. E., Kolb, C. E., Kurylo, M. J., Moortgat, G. K., Orkin, V. L., and Wine, P. H.: Evaluation No. 17, JPL Publication 10-6, Chemical Kinetics and Photochemical Data for Use in Atmospheric Studies, Jet Propulsion Laboratory, Pasadena, available at: http://jpldataeval.jpl.nasa.gov (last access: 22 February 2018), 2011.

Santee, M. L., Manney, G. L., Livesey, N. J., Foidevaux, L., MacKenzie, I. A., Pumphrey, H. C., Read, W. G., Schwartz, M. J., Waters, J. W., and Harwood, R. S.: Polar processing and development of the 2004 Antarctic ozone hole: First results from MLS on Aura, Geophys. Res. Lett., 32, L12817, https://doi.org/10.1029/2005GL022582, 2005.

Santee, M. L., MacKenzie, I. A., Manney, G. L., Chipperfield, M. P., Bernath, P. F., Walker, K. A., Boone, C. D., Froidevaux, L., Livesey, N. J., and Waters, J. W.: A study of stratospheric chlorine partitioning based on new satellite measurements and modeling, J. Geophys. Res., 113, D12307, https://doi.org/10.1029/2007JD009057, 2008.

Shi, Q., Jayne, J. T., Kolb, C. E., Worsnop, D. R., and Davidovits, P.: Kinetic model for reaction of $\mathrm{ClONO}_{2}$ with $\mathrm{H}_{2} \mathrm{O}$ and $\mathrm{HCl}$ and $\mathrm{HOCl}$ with $\mathrm{HCl}$ in sulfuric acid solutions, J. Geophys. Res., 106, 24259-24274, https://doi.org/10.1029/2000JD000181, 2001.

Smith, C. A., Pope, F. D., Cronin, B., Parkes, C. B., and Orr-Ewing, A. J.: Absorption cross sections of formaldehyde at wavelengths from 300 to $340 \mathrm{~nm}$ at 294 and $245 \mathrm{~K}$, J. Phys. Chem. A, 110, 11645-11653, https://doi.org/10.1021/jp063713y, 2006.

Solomon, S.: Stratospheric ozone depletion: A review of concepts and history, Rev. Geophys., 37, 275-316, https://doi.org/10.1029/1999RG900008, 1999.

Solomon, S., Garcia, R. R., Rowland, F. S., and Wuebbles, D. J.: On the depletion of Antarctic ozone, Nature, 321, 755-758, 1986.

Solomon, S., Portmann, R. W., Sasaki, T., Hofmann, D. J., and Thompson, D. W. J.: Four decades of ozonesonde measurements over Antarctica, J. Geophys. Res., 110, D21311, https://doi.org/10.1029/2005JD005917, 2005.

Solomon, S., Kinnison, D., Bandoro, J., and Garcia, R.: Simulation of polar ozone depletion: An update, J. Geophys. Res., 120, 7958-7974, https://doi.org/10.1002/2015JD023365, 2015.

Solomon, S., Ivy, D. J., Kinnison, D., Mills, M. J., Neely, R. R., and Schmidt, A.: Emergence of healing in the Antarctic ozone layer, Science, 353, 269-274, https://doi.org/10.1126/science.aae0061, 2016.

Toon, O. B., Hamill, P., Turco, R. P., and Pinto, J.: Condensation of $\mathrm{HNO}_{3}$ and $\mathrm{HCl}$ in winter polar stratospheres, Geophys. Res. Lett., 13, 1284-1287, 1986.

Wegner, T., Grooß, J.-U., von Hobe, M., Stroh, F., SumińskaEbersoldt, O., Volk, C. M., Hösen, E., Mitev, V., Shur, G., and 
Müller, R.: Heterogeneous chlorine activation on stratospheric aerosols and clouds in the Arctic polar vortex, Atmos. Chem. Phys., 12, 11095-11106, https://doi.org/10.5194/acp-12-110952012, 2012.

WMO: Scientific assessment of ozone depletion: 2014, Global Ozone Research and Monitoring Project-Report No. 55, Geneva, Switzerland, 2014.
Zafar, A. M.: Stratospheric ozone depletion: Analysis of heterogeneous chemistry in the Antarctic, no. 4394 in Berichte des Forschungszentrums Jülich, Forschungszentrum Jülich, available at: www.fz-juelich.de/zb/openaccess (last access 22 February 2018), 2016.

Zhong, W. and Haigh, J. D.: Improved broadband emissivity parameterization for water vapor cooling rate calculations, J. Atmos Sci., 52, 124-138, 1995. 